\title{
Antibiotic Usage in the Pediatric Population: The Need for Effective Role of Parents and Prescribers
}

\section{Pediyatrik Popülasyonda Antibiyotik Kullanımı: Ebeveynlerin ve Reçete Yazanların Etkili Rolüne Duyulan İhtiyaç}

Yusuf Karataş (0000-0002-2892-5625), Zakir Khan (0000-0003-1365-548X)

Çukurova University, Department of Pharmacology, Adana, Turkey

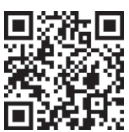

Keywords

Antibiotics, adverse drug reactions, pharmacotherapy, pediatrics, resistance

\section{Anahtar kelimeler}

Antibiyotikler, advers ilaç reaksiyonları, farmakoterapi, pediatri, direnç

Received/Geliş Tarihi : 09.11.2020

Accepted/Kabul Tarihi : 04.01.2021

DOI:10.4274/jcp.2021.0019

Address for Correspondence/Yazışma Adresi (Sorumlu Yazar):

Zakir Khan, Çukurova University, Department of Pharmacology, Adana, Turkey

\begin{abstract}
Antibiotics are an important aspect of pediatric medical treatment and infectious diseases are the leading cause of child mortality. Antibiotics are the cornerstone of the treatment for bacterial infections, and children received these drugs more frequently than any other class of medication. Inappropriate use of antibiotics is of international concern and promotion of appropriate and safe antibiotic usage is the need of the hour. The high percentage of inadequate antibiotic prescriptions in hospitals and the community is reported in the pediatric population around the globe. The improper and excessive use of antibiotics in children leads to resistance and adverse drug reactions (ADRs). Parents and prescribers influence the prescription of antibiotics in children. It is reported that only proper educational intervention by the right people with the right tools for both parents and prescribers can sufficiently improve the problem of inappropriate antibiotic practices and gradually eliminate the risk of antibiotic resistance. This narrative review paper provides an overview of the use, ADRs, allergy, errors, and off-label usage of antibiotics in children and also discusses the important role of the parents and prescriber in the use of antibiotics therapy.
\end{abstract}

$\ddot{O} z$

Antibiyotikler pediatrik tıbbi tedavinin önemli bir yönüdür ve enfeksiyon hastalıkları çocuk ölümlerinin önde gelen nedenidir. Antibiyotikler, bakteriyel enfeksiyonların tedavisinin temel taşıdır ve çocuklar bu ilaçları diğer ilaç sınıflarından daha sık almıştır. Antibiyotiklerin uygunsuz kullanımı uluslararası bir endişe kaynağıdır ve uygun ve güvenli antibiyotik kullanımının teşviki saatin ihtiyacıdır. Hastanelerdeki ve toplumdaki yetersiz antibiyotik reçetelerinin yüksek yüzdesi, dünya genelindeki pediatrik popülasyonda bildirilmektedir. Çocuklarda uygunsuz ve aşırı antibiyotik kullanımı direnç ve advers ilaç reaksiyonlarına (ADR'ler) yol açar. Ebeveynler ve reçete yazanlar, çocuklarda antibiyotik reçetesini etkiler. Hem ebeveynler hem de reçete yazanlar için doğru araçlarla, yalnızca doğru kişiler tarafından uygun eğitim müdahalesinin, uygun olmayan antibiyotik uygulamaları sorununu yeterince iyileştirebileceği ve antimikrobiyal direnç riskini kademeli olarak ortadan kaldırabileceği bildirilmektedir. Bu anlatı gözden geçirme belgesi, çocuklarda antibiyotiklerin kullanımı, ADR'ler, alerji, hatalar ve endikasyon dışı kullanımına genel bir bakış sağlamakta ve antibiyotik tedavisinin kullanımında ebeveynlerin ve reçete yazanın önemli rolünü tartışmaktadır. 


\section{Introduction}

World Health Organization (WHO) describe the ideal medication for children as "a drug that suits the child's age, medical condition, and body weight and is available in a flexible solid oral dosage form that can be taken completely, diluted in a variety of liquids or sprinkled on food, and making it easier for children to take it (1). Infectious diseases are one of the most common causes in the pediatric population for seeking emergency treatment. More than 5 million children under the age of five die each year worldwide, with pneumonia, diarrhea, malaria, and other neonatal causes (2). These morbidities situations can be treated with safe and effective medications. Whereas, inappropriate usage of the medications has led to adverse drug reactions (ADRs) and resistance issues $(3,4)$.

The promotion of appropriate and safe use of drugs is a global need $(5,6)$. Over the past decades, the prevalence of antibiotic resistance (AMR) has increased to bacteria that cause common infections in children at a global level $(1,3,4)$. The usage pattern of antibiotics among children also vary between countries $(2,5,6)$. The role of prescribers and parents in the appropriate use of antibiotics is crucial. In this mini analysis, we discuss the use, ADRs, allergy, errors, and off-label usage of antibiotics in children. We also explore the important role of parents and prescribers in the use of antibiotics therapy.

\section{Antibiotics and Children}

Antibiotics are a drug that prevents the growth of microorganisms or kills them. The word antibiotic means anti- against and biotic- used for life. Antibiotics are the cornerstones of the treatment of bacterial infections and children received these drugs more frequently than any other class of medication (7). However, the improper and excessive use of antibiotics in children leads to resistance and ADRs (6-8). The high percentage of inadequate antibiotic prescriptions in hospitals and the community is reported in the pediatric population around the globe $(8,9)$. The prescription of these medicines is reported to be inappropriate in up to $30-50 \%$ of cases (9). Antibiotics can also cause ADRs and drug toxicity on the intestinal microbiota and enteric immune system (8-10). The lack of relevant pediatric clinical trials on antibiotics has led to a shortage of evidence-based knowledge (11). All the medical leaders and possibly all members of society must be aware of the problem of antibiotic resistance. A plan for an effective strategy to increase appropriate antibiotic use around the world is highly needed $(7,12)$.

\section{Adverse Drug Reactions}

An adverse drug reaction (ADR) implies damage from the use of medication. ADRs are further divided into predictable and unpredictable reactions. Predictable reactions are characterized as occurring in healthy children, linked to known pharmacological actions of the drug and typically dose dependent. On the other hand, unpredictable reactions occur in vulnerable children, unrelated to pharmacological activities actions, and are not a dose dependent. Unpredictable reactions may also be further subdivided into drug intolerance, drug idiosyncrasy, drug allergy, and pseudo-allergic reactions $(13,14)$. Historically, the impression has been given that children are at a lower risk of ADRs than adults (15). While the majority of this research has been done among adults, there are a limited but growing number of studies that show that children do have a significant risk for ADRs $(15,16)$. The fact that there is a significant risk of ADR in children is partly due to known risk factors and partly due to the nature of pharmacotherapy in children (17). Antibiotics are significantly overused, and a certain predictable rate of adverse reactions can be associated with all classes of antibiotics. Multiple drug-resistant infections are highly prevalent (10). Therefore, when making treatment decisions every prescriber needs to be aware of the very real risk of ADRs due to antibiotic treatment.

\section{Antibiotic Allergy}

Based on the traditional Gell and Coombs classification system, a common definition is to categorize allergic reactions as either immediate (response within one hour after the drug administration) or non-immediate (response more than one hour after the drug administration; often days to weeks). These reactions can also be classified as Type I (immunoglobulin [IgE]-mediated), Type II (cytotoxic), type III (immune complex), and type IV (delayed hypersensitivity) (18). Data on the prevalence and incidence of antibiotic hypersensitivity reactions are limited, particularly in pediatric age and vary globally. 
Antibiotic allergy constitutes roughly 5-10 percent of all adverse drug reactions $(13,19)$. It was noted that ADRs constitute a "major public health issue" in children. Specifically, the recent focus is on the assessment of children with antibiotic allergy such as beta-lactam allergy due to the amoxicillin, which is the most used drug in children and also causes well-known ADRs (19). A key point for antibiotic allergy management is to make a proper diagnosis and prescribe a safe and effective alternative antibiotic (20,21). Furthermore, there is an urgent need for the implementation of an effective antibiotic stewardship program in pediatric health care specialties. Therefore, the prescribers should properly inform the caregiver about the risks of avoiding certain types of antibiotics ADRs due to allergy. Prescribers should be able to evaluate and/or refer individuals with reported antibiotic allergy or ADRs safely and efficiently and should know when to perform diagnostic tests or desensitization $(19,22)$.

\section{Medication Errors}

Medication error (ME) is described briefly as any preventable incident that may lead to inappropriate use of a drug or cause patient harm while the drug is under the control of the health care provider, patient, or consumer (23). Globally, per year ME's economic effect is estimated at United States Dollar (USD) 42 billion (24). ME has been reported to occur more frequently in pediatrics than in other populations $(25,26)$. Potential contributing factors behind such incidents may include: excessive use of unlicensed or off-label medicines (25), lack of appropriate dosing knowledge for children $(26,27)$, the difference in age, interpatient variation, need for stock drug dilution $(28,29)$, lack of computerized order entry (COE) and unit-based clinical pharmacists (30). In the pediatric treatment care situation, the error rate may increase due to the speedy response and a large number of prescriptions (23). The burden of mortality and morbidity associated with ME is high and WHO has pledged to a global work plan to reduce the harm caused to patients by ME to $50 \%$ by 2022 (24).

A detailed and organized research work on this topic would be desirable and possibly also beneficial. Generally, raising the health care staff awareness about this issue and relevant continuing education alone results in fewer MEs. Access to data on pediatric drug therapy (age-specific doses, preparation, and contraindications) must be assured. The data can be made available online or in the form of tables or booklets that may be carried in staff pockets. Prescriptions should be written on standard prescription forms and the lowest possible number and concentration of drugs should be used, whenever possible. Where prescriptions are issued orally, a communication structure must be established in which a structured, complete request is made and repeated in full by the recipient as confirmation $(31,32)$.

\section{Off-label Antibiotic Usage}

The usage of a drug that is not included in the package insert (approved labeling) for that drug is referred to as "off-label" use (33). Off-label drug use remains a major public health issue, particularly for infants, young children, and children with rare diseases. It is reported that many of the drugs prescribed to children are reported to be used outside of their approved doses, age ranges, indications and routes of administration (34-36). Antibiotics are the most common drugs administered to children (36-38). Off-label antibiotic use can cause significant damage to the developing fetus or infant, with one of the best examples being the chloramphenicol-related grey baby syndrome (39), and also resulting in many mild, but not negligible, adverse events requiring hospitalization or additional therapies $(36,40)$. Unlicensed and off-label prescribing is a global phenomenon (34). Regular research studies in children are urgently required to reduce the offlabel drug use problems (36). Worldwide educational campaigns should be introduced to enhance the awareness of pediatricians about the use of antibiotics in children and to minimize unregulated prescription behaviors which could increase the risk of antibiotic resistance (34).

\section{Parents Role}

Globally, a variation in antibiotic use practices reflect differences in local drug policies, barriers to access to treatment, and preferences of health care providers and parents (9). Previous studies reported that more than $40 \%$ of parents make errors while dosing liquid medication $(41,42)$. The other most common errors committed by parents, such as the use of a common spoon instead of a dispenser for the administration of antibiotics, failing to shake the contents of the bottle of antibiotics, not checking the 
expiry date on the packaging of the medication, not knowing about the administration of the medication with meals, dissolving the drug in the child's milk, insist on the same drug, stop the antibiotics once symptoms subside and the child seems to be healthy, rush to give the child antibiotics for recurrent or chronic diseases and they do not inform the pediatrician about potential allergies or side effects of the previously used antibiotic $(43,44)$.

Consequently, parental malpractices and overconsumption of antibiotics contribute to germ resistance. Parents or careers should also understand the nature of the illness, the course of antibiotics, and should obey the pediatrician's specific advice on effective antibiotic therapy for their children (45). Unfortunately, many parents have a bad habit of having an antibiotic at home for "every event". This is a bad practice as only a qualified prescriber can decide whether the child needs antibiotics and of course each illness requires a different antibiotic. Parents should avoid the use of unnecessary antibiotics when a child becomes ill. The appropriate antibiotics for the specific disease should always be prescribed by the doctor (46). Multifaceted educational approaches involving parents are needed for the rational use of antibiotics.

\section{Prescriber Role}

There are some additional challenges to the use of antibiotics in children. The off-labeled and unlicensed use of medicinal products is common, which may increase the risk of preventable harm due to antibiotic therapy (13). A small mistake in the dosage of medication prescribed to children has a greater chance of harm compared to adults. Pediatric prescription also requires weight-related dose adjustments and other dose calculations that are less common in adults (47). Studies have indicated that prescribing antibiotics in children is influenced by prescriber characteristics such as the location of medical training, specialization, years in practice, affiliation to the hospital, and type of practice (private or clinic) (48-50). Prescribers may feel that they do not have the time to adequately monitor doses according to the child's weight, which is change with time and may, therefore, lead to incorrect prescriptions being written and dispensed $(47,51)$. The availability of antibiotics without the prescription of a doctor varies, and the laws limiting access to antibiotics is still poorly enforced (52). Drug shortages in some settings may be a significant limiting factor in antibiotic use. Also, cultural preferences s and high parental demand affect antibiotic practices. Even if prescribers are aware of the appropriate antibiotic usage, there may be differences between knowledge and practice exist (53).

It is recommended that an empiric therapy must be followed when an infection is believed to be responsible for a disease, but the actual pathogen has not been identified. It includes the use of a broadspectrum antibiotic based on the identified signs and symptoms and is undertaken to await tests from the laboratory, which can take several days. On the other side, when the pathogenic microorganism responsible is already recognized or established, definitive therapy can be initiated. This will normally require the use of an antibiotic that is narrow spectrum $(54,55)$. The antibiotic option will also be dependent on their cost (56). Furthermore, accurate identification is important because it can minimize the cost and toxicity of antibiotic therapy and reduce the potential for resistance to antibiotics $(55,57)$. Although many of these practices are not considered evidence-based antibiotic prescribing, they do occur regularly $(55,58)$. The intervention targeting health care prescribers would have the greatest impact on the use of antibiotics in the pediatric population. Interventions such as academic detailing, periodic training, and prescribing feedback have proved successful in reducing inappropriate antibiotic usage $(56,58)$.

\section{Conclusion}

There is an urgent need to improve the quality of antibiotic prescriptions in the pediatric population. Because of the growing threat posed by antibiotic resistance, adverse reactions, and other harmful consequences, this has become a global health priority. Rational prescribing practices and the pediatric antibiotic stewardship programs (ASPs) must be implemented in all countries including Turkey. Both physicians and parents need simultaneous training to reduce the overuse of antibiotics. It is concluded that only proper educational intervention by the right people with the right tools for doctors and patients can sufficiently improve the problem of inappropriate antibiotic practices and eliminate the risk of antibiotic resistance, which insidiously results in major medical and social problems. 
Conflict of Interest: No conflict of interest was declared by the authors.

Financial Disclosure: The authors declared that this study received no financial support.

\section{References}

1. Medicines for children. Geneva: World health organization (WHO); 2020 (https://www.who.int/medicines/access/motherchildren/med_child/e/).

2. United Nations Children's Fund (UNICEF). Under-five mortality; 2019 (https://data.unicef.org/topic/child-survival/ under-five-mortality/).

3. Ofori AR, Agyeman AA. Irrational use of medicines-a summary of key concepts. Pharmacy 2016;4(4):35. doi:10.3390/ pharmacy 4040035.

4. Yewale VN, Dharmapalan D. Promoting appropriate use of drugs in children. Int J Pediatr 2012;2012:906570. doi: $10.1155 / 2012 / 906570$.

5. Center for disease control and prevention (CDC). Antibiotic/ Antimicrobial Resistance (AR/AMR); 2019 (https://www.cdc. gov/drugresistance/index.html).

6. Aslam B, Wang W, Arshad MI, Khurshid M, Muzammil S, Rasool MH, et al. Antibiotic resistance: a rundown of a global crisis. Infect Drug Resist 2018;11:1645-58, doi: 10.2147/IDR. S173867.

7. Lee CR, Cho IH, Jeong BC, Lee SH. Strategies to minimize antibiotic resistance. Int $J$ Environ Res Public Health 2013;10(9):4274-4305, doi:10.3390/ijerph10094274.

8. Tham DWJ, Abubakar U, Tangiisuran B. Prevalence and predictors of antibiotic use among children visiting the emergency department in a tertiary hospital in Malaysia. Eur J Pediatr 2020;179:743-8, doi: 10.1007/s00431-019-03560-z.

9. Rogawski ET, Platts-Mills JA, Seidman JC, John S, Mahfuz M, Ulak M, et al. Use of antibiotics in children younger than two years in eight countries: a prospective cohort study. Bull World Health Organ 2017:95(1):49-61, doi:10.2471/BLT.16.176123.

10. Ventola CL. The antibiotic resistance crisis: part 1: causes and threats. PT 2015;40(4):277-83, (https://pubmed.ncbi.nlm.nih. gov/25859123/).

11. Thompson G, Barker CI, Folgori L, Bielicki JA, Bradley JS, Lutsar I. Global shortage of neonatal and paediatric antibiotic trials: rapid review. BMJ open 2017;7(10):e016293, doi:10.1136/ bmjopen-2017-016293.

12. Milani RV, Wilt JK, Entwisle J, Hand J, Cazabon P, Bohan JG. Reducing inappropriate outpatient antibiotic prescribing: normative comparison using unblinded provider reports. BMJ Open Qual 2019;8(1):e000351, doi:10.1136/ bmjoq-2018-000351.

13. Abrams E, Netchiporouk E, Miedzybrodzki B, Ben-Shoshan M. Antibiotic allergy in children: more than just a label. Int Arch Allergy Immunol 2019;180(2):103-112, doi: 10.1159/000501518.

14. Coleman JJ, Pontefract SK. Adverse drug reactions. Clin Med 2016;16(5):481-5. doi:10.7861/clinmedicine.16-5-481.

15. Rieder M.Adverse drug reactions in children: pediatric pharmacy and drug safety. J Pediatr Pharmacol Ther 2019;24(1):4-9, doi:10.5863/1551-6776-24.1.4.

16. Gallagher RM, Mason JR, Bird KA, Kirkham JJ, Peak M, Williamson PR, et al. Adverse drug reactions causing admission to a paediatric hospital. PLoS One 2012;7(12): e50127, doi: 10.1371/journal.pone.0050127.

17. Lombardi N, Crescioli G, Bettiol A, Marconi E, Vitiello A, Bonaiuti R, et al. Characterization of serious adverse drug reactions as cause of emergency department visit in children: a 5-years active pharmacovigilance study. BMC Pharmacol Toxicol 2018; 19:16, doi:10.1186/s40360-018-0207-4.

18. Brockow K, Przybilla B,Aberer W, Bircher AJ, Brehler R, Dickel $\mathrm{H}$, et al. Guideline for the diagnosis of drug hypersensitivity reactions. Allergo J Int 2015;24(3):94-105, doi: 10.1007/s40629015-0052-6.

19. Calamelli E, Caffarelli C, Franceschini F, Saretta F, Cardinale F, Bernardini R, et al. A practical management of children with antibiotic allergy. Acta Biomed 2019;90(3-S):11-9, doi:10.23750/ abm.v90i3-S.8157.

20. Franceschini F, Bottau P, Caimmi S, Cardinale F, Crisafulli G, Liotti L, et al. Mechanisms of hypersensitivity reactions induced by drugs. Acta bio-medica: Atenei Parmensis 2019;90(3):44-51. doi: 10.23750/abm.v90i3-S.8160.

21. Blumenthal KG, Peter JG, Trubiano JA, Phillips EJ. Antibiotic allergy. Lancet 2019;393(10167):183-198, doi:10.1016/S01406736(18)32218-9.

22. Srinivasan A. Antibiotic stewardship: Why we must, how we can. Cleve Clin J Med 2017;84(9):673-9, doi:10.3949/ ccjm.84gr.17003.

23. Shitu Z, Aung MMT, Kamauzaman THT, Rahman AFA. Prevalence and characteristics of medication errors at an emergency department of a teaching hospital in Malaysia. BMC Health Serv Res 2020;20:56, doi: 10.1186/s12913-020-4921-4.

24. World Health Organization (WHO). Global patient safety challenge: medication without harm; 2017, (http://www.who. $\mathrm{int} /$ patientsafety/medication-safety/medication-without-harmbrochure/en/).

25. Alghamdi AA, Keers RN, Sutherland A, Ashcroft DA. Prevalence and nature of medication errors and preventable adverse drug events in paediatric and neonatal intensive care settings: a systematic review. Drug Saf 2019;42:1423-1436, doi:10.1007/ s40264-019-00856-9.

26. Kaushal R, Bates DW, Landrigan C, McKenna KJ, Clapp MD, Federico F, et al. Medication errors and adverse drug events in pediatric inpatients. JAMA 2001;285(16):2114-20.

27. Conroy S. Association between licence status and medication errors. Arch Dis Child. 2011;96(3):305, doi:10.1136/ adc.2010.191940.

28. Iftikhar S, Sarwar MR, Saqib A, Sarfraz M, Shoaib QU. Antibiotic prescribing practices and errors among hospitalized pediatric patients suffering from acute respiratory tract infections: a multicenter, cross-sectional study in pakistan. Medicina 2019;55(2):44, doi:10.3390/medicina55020044.

29. Zeleke A, Chanie T, Woldie M. Medication prescribing errors and associated factors at the pediatric wards of dessie referral hospital, northeast Ethiopia. Int Arch Med 2014;3(7):18, doi: 10.1186/1755-7682-7-18.

30. Poole RL, Carleton BC. Medication errors: neonates, infants and children are the most vulnerable!. J Pediatr Pharmacol Ther 2008;13(2):65-67, doi:10.5863/1551-6776-13.2.65.

31. Kaufmann J, Laschat M, Wappler F. Medication errors in pediatric emergencies: a systematic analysis. Dtsch Arztebl Int 2012;109(38):609-616, doi:10.3238/arztebl.2012.0609. 
32. Kozer E, Scolnik D, Keays T, Shi K, Luk T, Koren G: Large errors in the dosing of medications for children. N Engl J Med 2002; 346: 1175-6.

33. Frattarelli DA, Galinkin JL, Green TP, Johnson TD, Neville KA, Paul IM, et al. Off-label use of drugs in children. Pediatrics 2014;133(3):563-7, doi: 10.1542/peds.2013-4060.

34. Tukayo BLA, Sunderland B, Parsons R, Czarniak P. High prevalence of off-label and unlicensed paediatric prescribing in a hospital in Indonesia during the period Aug.-Oct. 2014. PLoS ONE 2020;15(1): e0227687, doi: 10.1371/journal.pone.0227687.

35. Garbe MC, Lees J, Aziz N, Chaaban H, Miller JL, et al. Offlabel medication use in children, more common than we think: a systematic review of the literature. J Okla State Med Assoc 2018;111(8):776-83.

36. Porta A, Esposito S, Menson E, Spyridis N, Tsolia M, Sharland $\mathrm{M}$, et al. Off-label antibiotic use in children in three European countries. Eur J Clin Pharmacol 2010;66(9):919-27, doi: 10.1007/s00228-010-0842-1.

37. Mukattash TL, Hayajneh WA, Ibrahim SM, Ayoub A, Ayoub $\mathrm{N}$, Jarab AS, et al. Prevalence and nature of off-label antibiotic prescribing for children in a tertiary setting: A descriptive study from Jordan. Pharm Pract 2016;14(3):725, doi:10.18549/ PharmPract.2016.03.725.

38. Zingg W, Posfay-Barbe KM. Antibiotic use in children - off-label use. Curr Drug Targets 2012;13(7):885-92.

39. Holt D, Harvey D, Hurley R. Chlorampenicol toxicity. Adverse Drug React Toxicol Rev 1993;12:83-95.

40. Horen B, Montastruc JL, Lapeyre MM. Adverse drug reactions and offlabel drug use in paediatric outpatients. $\mathrm{Br} \mathrm{J}$ Clin Pharmacol 2002;54:665-670.

41. Parand A, Garfield S, Vincent C, Franklin BD. Carers' medication administration errors in the domiciliary setting: a systematic review. PLoS One 2016;11(12):e0167204, doi: 10.1371/journal. pone. 0167204 .

42. Yin HS, Dreyer BP, Moreira HA, Van SL, Rodriguez L, Boettger $\mathrm{S}$, et al. Liquid medication dosing errors in children: role of provider counseling strategies. Acad Pediatr. 2014;14(3):262270, doi:10.1016/j.acap.2014.01.003.

43. Kourkouta L, Kotsiftopoulos CH, Papageorgiou M, Iliadis CH, Monios A. Use of antibiotics in child age - a review. Prog Health Sci 2018;8(1):162-6.

44. Al-Ramahi RJ, Zaid AA, Anabousi H. Problems associated with reconstitution, administration, and storage of antibiotic suspensions for pediatrics: a cross-sectional study in Nablus city, Palestine. BMC Res Notes 2015;8:760. doi:10.1186/s13104-0151746-z.

45. Finkelstein JA, Dutta LM, Meyer R, Goldman R. Childhood infections, antibiotics, and resistance: what are parents saying now?. Clin Pediatr 2014;53(2):145-50, doi: $10.1177 / 0009922813505902$.
46. Leibovici L, Shraga I, Andreassen S. How do you choose antibiotic treatment?. BMJ 1999;318(7198):1614-6. doi:10.1136/ bmj.318.7198.1614.

47. World health organization (WHO). Medication errors; $2016 \quad$ (https://apps.who.int/iris/bitstream/hand le/10665/252274/9789241511643-eng.pdf?sequence=1).

48. Di Martino M, Lallo A, Kirchmayer U, Davoli M, Fusco D. Prevalence of antibiotic prescription in pediatric outpatients in Italy: the role of local health districts and primary care physicians in determining variation. A multilevel design for healthcare decision support. BMC Public Health 2017;17(1):886. doi:10.1186/s12889-017-4905-4.

49. Livorsi D, Comer A, Matthias MS, Perencevich EN, Bair MJ. Factors influencing antibiotic-prescribing decisions among inpatient physicians: a qualitative investigation. Infect Control Hosp Epidemiol. 2015;36(9):1065-1072, doi:10.1017/ ice.2015.136.

50. Zolaly MA, Hanafi MI. Factors affecting antibiotics' prescription in general pediatric clinics. J Taibah Univ Med Sci 2011;6(1):3341, doi:10.1016/S1658-3612(11)70154-8.

51. Velo GP, Minuz P. Medication errors: prescribing faults and prescription errors. Br J Clin Pharmacol 2009;67(6):624-628, doi:10.1111/j.1365-2125.2009.03425.x.

52. Ayukekbong JA, Ntemgwa M, Atabe AN. The threat of antimicrobial resistance in developing countries: causes and control strategies. Antimicrob Resist Infect Control 2017;6:47, doi:10.1186/s13756-017-0208-x.

53. Chem ED, Anong DN, Akoachere JKT. Prescribing patterns and associated factors of antibiotic prescription in primary health care facilities of kumbo east and kumbo west health districts, north west Cameroon. PLoS One 2018;13(3):e0193353. doi:10.1371/ journal.pone.0193353.

54. Le Saux N. Antimicrobial stewardship in daily practice: Managing an important resource. Paediatr Child Health 2014;19(5):261270, doi:10.1093/pch/19.5.26.

55. Leekha S, Terrell CL, Edson RS. General principles of antimicrobial therapy. Mayo Clin Proc 2011;86(2):156-167, doi:10.4065/mcp.2010.0639.

56. Anthea D, Mieke VD, Thea VDM, Parker M. Antibiotic prescribing for the future: exploring the attitudes of trainees in general practice. British Journal of General Practice 2014; 64 (626): e561-e567, doi:10.3399/bjgp14X681373.

57. Simoens S. Factors affecting the cost effectiveness of antibiotics. Chemother Res Pract 2011;2011:249867, doi:10.1155/2011/249867.

58. Kozyrskyj AL, Dahl ME, Chateau DG, Mazowita GB, Klassen TP, Law BJ. Evidence-based prescribing of antibiotics for children: role of socioeconomic status and physician characteristics. CMAJ 2004;171(2):139-145, doi:10.1503/cmaj.1031629. 